\title{
The role of intergenerational social capital in diminishing student attrition
}

\author{
GABRIELLA PUSZTAI* \\ Doctoral Program on Educational and Cultural Sciences, University of Debrecen, Debrecen, Hungary
}

(Received: July 9, 2018; accepted: September 25, 2018)

\begin{abstract}
Background and aims: Higher education was reformed through the Bologna Process with the hope that an increasing number of students will get a degree faster than before due to the short cycle of bachelor's programs. However, the change in structure has not reduced student attrition in Western Europe. Even in the 2010s, understanding the phenomenon of attrition is one of the most significant challenges in higher education research. In Hungary, almost two fifths of bachelor's students and one fifth of master's students leave higher education without earning a degree. Methods: When examining student attrition, we may use data on institutions or individuals. Institutional data reveal the proportion of those who continue their studies without interruption (retention), while data on the individual level allow the investigation of students' expectations about their own chances of getting a degree (persistence). Results: By comparing attrition rates among those who pursued higher education in 2010 and 2014 at different faculties (data from the Higher Education Information System - FIR) with data from a regional student survey (IESA database), we have found that faculties with high retention rates also demonstrate a large proportion of self-reported persistent students. Furthermore, we have explored the effect of individual traits (demographic characteristics and socioeconomic status), institutional factors (size, selectivity, maintainer, and prestige), and embeddedness (multiplexity and strength of different social networks) on student persistence. Conclusion: We have shown that institutional factors and embeddedness have a more significant impact than demographic and social characteristics, which individuals have before entering higher education.
\end{abstract}

Keywords: persistence; student attrition; higher education

\section{POSSIBLE APPROACHES TOWARD STUDENT ATTRITION}

In connection with our research on the indicators and underlying causes of student efficiency in a Central and Eastern European cross-border region, it has come to our attention that the international literature offers no consensus on the definition and appropriate measurement of student efficiency. In our studies, we have argued that student efficiency is best measured by complex indicators, which consist of predictors of long-run achievements (Pusztai, 2017). However, most international researchers approach the question from a negative perspective: they investigate student inefficiency, attrition, dropping out, student departure, non-completion, or disillusion with education goals or the institution. Higher education was reformed through the Bologna Process with the hope that an increasing number of students will get a degree faster than before due to the short cycle of bachelor's programs (Pusztai \& Szabó, 2008). Nevertheless, the change in structure has not reduced student attrition (Kehm, 2014; Wolter, Diem, \& Messer, 2014). It is worthwhile to investigate the patterns of student attrition between entry and graduation in Hungary as well, since statistics show that two fifths of bachelor's students, one fifth of master's students, and half of doctoral students leave higher education without earning their degree (Derényi, 2015;
Pusztai, 2009). Neighbouring countries also exhibit a large proportion of higher education dropouts (Hatos \& Pop, 2013). This study contributes to the line of research in which the predictive factors of student attrition are searched for and the interconnected effects of student persistence are examined. First, we explore the possible approaches toward the phenomena of retention and persistence, then we provide an overview of explanatory models and finally, we present our analysis.

The definition and measurement of student retention and persistence vary on different levels of analysis substantially, with some studies even using the two terms interchangeably. A possible aspect of investigating student attrition is the institutional perspective. The term "retention" is frequently used when the continuation rate of a student cohort or the ratio between graduated and admitted students is discussed (Mortenson, 2012). When examining retention, it is vital to create ratios from compatible data, that is, one must compare groups of students in a certain field or at a given institution who started their studies at the same time. Statistical databases that are available on non-continuation of higher

\footnotetext{
* Correspondence: Prof. Dr. Gabriella Pusztai, Head of Doctoral Program on Educational and Cultural Sciences, University of Debrecen, Egyetem Square 1, Debrecen 4032, Hungary; Phone: +3652512 900; Fax: +3652512 922; e-mail: gabriela.pusztai@ gmail.com
}

This is an open-access article distributed under the terms of the Creative Commons Attribution 4.0 International License, which permits unrestricted use, distribution, and reproduction in any medium, provided the original author and source are credited, a link to the CC License is provided, and changes - if any - are indicated. (SID_1) 
studies in Hungary identify multiple scenarios: students decide to terminate their studies themselves, they do not meet academic or examination criteria, they are unable to cover tuition and other expenses, or discontinue their studies due to medical reasons (Fenyves et al., 2017). The scenarios, however, do not reveal the actual circumstances of attrition in detail.

There is a broad spectrum between the uninterrupted path toward a degree in higher education and typical attrition, which leaves one without a degree. Early studies on the topic focused on voluntary non-completion, and did not account for students dismissed due to academic and behavioral-ethical reasons. Therefore, attrition included only those who decided to terminate their studies voluntarily (Tinto, 1975). Attrition might also be approached by examining students who have grown hesitant about the continuation of their studies as they are in permanent awareness of everyday experiences and interactions, which may steer them toward retention or departure (Tinto, 1993).

In the literature, we find some panel studies. Tinto's attrition model, proposed in the 70s, was first tested at a large university with 10,000 bachelor's students by following 1,500 freshmen, of whom some 800 responded a year later, with about one tenth dropping out (Pascarella \& Terenzini, 1980; Tinto, 1975). Panel studies outside higher education have also been attempted by following cohorts of secondary school students (Sciarra, Seirup, \& Sposato, 2016). These studies always face the crucial problem that as time progresses, the number of those who do not respond grows higher. To circumvent falling response rates, researchers often look for indicators, which can also be used in cross-sectional analysis. These include the perception of academic challenges in higher education, a related indicator: commitment to one's studies, and data on the time and effort devoted toward studying (Astin, 1993). It seems that expectations on the successful completion of studies are closely connected to decisions and behavior as a student. Thus, in this study, we consider students persistent, if they are determined to complete their education.

\section{Higher education socialization and student persistence}

Higher education research does not always consider the quality and quantity of relationships, which influence the institutional effectiveness of education the most. The heterogeneity of the student body, however, has focused attention on the socialization processes in higher education, which is defined by the entry into the gravitational field of the social network at the higher education institution and by growing somewhat distant from external social networks (Tinto, 1975, 1993). There seems to be a consensus that attrition follows from unsuccessful student socialization (Heublein, 2014). Based on previous analyses, we differentiate between reconstructive and constructivist approaches of student socialization in the model frameworks of institutional socialization in higher education (Pusztai, 2015). Whereas reconstructive views focus on the transmission of a certain culture in higher education, during which students, voluntarily or not, obey macrostructures that exist independently from them, the constructivist approach underlines that higher education operates in an environment in which actors shape others' and their own beliefs actively (Pusztai, 2015; Somlai, 1997).

According to a version of the reconstructive view, the improvement in knowledge and competencies, and the steps toward becoming a professional can be planned precisely (Szczepanski, 1969; Weidman \& Stein, 2003). Critical theories of socialization argue that uninterrupted continuation of higher education is determined by socially dominant inequalities and the socioeconomic status of the family (Ceglédi, Tóbi, \& Harsányi, 2016; Reay, Crozier, \& Clayton, 2009). This implies that differences in student persistence arise from status inequality, similarly to the achieved level of competence and the variation in previous school efficiency. The critical approach suggests that a poor decision about a higher education program, which leads to early departure, is partly due to the lack of appropriate professional orientation, which is based on the realities of the socioeconomic environment and the actual possibilities offered by higher education (Nakajima, Dembo, \& Mossler, 2012).

By contrast, the constructivist approach stresses that student groups are active participants in the formation of what higher education means to them. Constructivist analyses on higher education focus on discursivity by pointing out the momentary and unique nature of mutual reflection (Huber, 1991). In the analysis of higher education processes, it might be more appropriate to turn to another version of the constructivist perspective, which highlights the importance of students' contextual communities in which they become embedded (Pusztai, 2015).

Differences between degree programs and fields can be observed regardless of their social base of mobilization. In each field, high admission requirements and favorable placement opportunities increase the proportion of persistent students (French, Immekus, \& Oakes, 2005; Ulriksen, Madsen, \& Holmegaard, 2017). Professional identity, disciplinary values, and strong ties to social networks also seem to explain persistence (Ulriksen et al., 2017).

Strong ties to academic and social networks have also been shown to exert an effect in the earliest study on attrition, which has revealed a connection between determination to complete a degree and attachment to the institution (Tinto, 1993). This explanatory model suggests that those who have an above average risk of attrition cannot be identified before entry, since social attachment is the key factor: until students grow distant from the communities, which were important to them before higher education, they are not able to integrate into their higher education institution. Influential studies have since confirmed Tinto's integration theory (Astin, 1993; Pascarella \& Terenzini, 2005).

Some researchers characterize the resources from the student's relationships as social capital (Altbach, 2009; Kim \& Schneider, 2005; Perna \& Titus, 2005). In our previous studies, we showed the strong connection between attachment to social networks, the direction and strength of ties, the multiplexity of relationships, and the interpretations, which impact students' higher education activities. Consequently, we introduced the concept of student embeddedness to analyze students' institutional relations systematically (Pusztai, 2015). As in the literature, we made 
a distinction between externally and internally attractive relationships.

As we have established, it is very important that lecturers and professors should be available outside the lecture hall and the possibility of constant communication with them should exist. An influential factor is the perception of fellow students' commitment, that is, to what extent they consider it necessary to engage in academic activities and take part in the campus community (Pusztai, 2015; Sciarra et al., 2016). While international studies have revealed the diminishing effect of strong intragenerational ties among students on attrition, the first cohorts in the changed structure of Hungarian higher education after the Bologna Process exhibit lower efficiency when embedded in the campus community (Pusztai, 2015).

External intergenerational relationships should also be considered. At the turn of the millennium, it was proposed that certain student groups might achieve their academic goals due to the notification or even inclusion of parents (Tierney, 2000). Parents can be involved in many ways, not only as donors but also as a target group for family events and parental clubs. At universities in the United States, parent relations offices inform them and organize activities for them. The literature also considers parents as a key interest group (Wartman \& Savage, 2015). Impact assessments about institutional programs include parents regarding them as active partners in their child's higher educational development and in the preparation of a successful graduation. Parents maintain an increasingly direct relationship with universities and colleges, and could even be involved in trainings, which prepare and support their child's higher education participation. Previously, parents' support and involvement were considered as unwanted intervention, which hinders the process of becoming independent, but recent research suggests that they might contribute to students' commitment to their studies (Barefoot, 2004; Braxton, 2000; Perna \& Titus, 2005; Wartman \& Savage, 2015; Wolf, Sax, \& Harper, 2009).

\section{HYPOTHESES AND VARIABLES}

Our research question is the following: what is the effect of the strength and multiplexity of intraorganizational and extraorganizational, intergenerational, and intragenerational relationships on students' perseverance with academic goals, and how stable is this effect with varied demographic, social, and institutional characteristics? Our hypotheses refer to the relationships between family status, institutional characteristics, students' embeddedness in the social network, and persistence. We hypothesize that basic indicators of social status, in particular, parents' level of education impacts students' perseverance with their studies the most as it can be well utilized in education institutions. In accordance with international literature, we expect that institutions with flexible requirements and programs to aid the progress of the disadvantaged have more persistent students (Heublein, 2014). This implies that strict and selective institutions have a lower proportion of persistent students.

Based on our previous findings, we also assume that the student integration theory, which is widely discussed and corroborated in the literature, cannot be considered a homogenous phenomenon in the social context of higher education. We argue that embeddedness in intergenerational and intragenerational social networks based on the poles of the intra-extra campus axis affects students' higher education persistence differently. We hypothesize that close, intraorganizational, and intragenerational ties increase the perseverance of lower-educated parents' children, whereas children of higher-educated parents, who speak the same language with teachers, establish internal, intergenerational relationships, which can enhance their perseverance. In other words, we expect the direction of social networks to differ by the parents' level of education.

Extraorganizational and intergenerational ties refer to the relationships between students and parents. As high-educated parents' children are endowed with contacts, which bear a relevance to higher education, we expect parents' high level of education, strong extraorganizational and intergenerational embeddedness, and substantial student persistence to correlate. With respect to strong, extraorganizational, and intragenerational ties, we presume that children of parents with a low level of education have fewer relationships within their generation, and even those connections are mainly directed toward socially homogeneous groups. This suggests that their relationships might lack an intellectual factor, which could hinder their perseverance with their studies.

Our analysis is based on the Institutional Effect on Students' Achievement in Higher Education (IESA) database, which was created in 2015. Its detailed description can be found in a book with our previous research findings (Pusztai, Bocsi, \& Ceglédi, 2016). The database contains data from 2017 students at 13 higher education institutions of five countries in the Carpathian Basin. We have compared data from Romanian, Ukrainian, Serbian, and Slovakian higher education institutions and faculties, which offer courses in Hungarian with Eastern Hungarian institutions, as the latter are similar to the former as regards the share of underprivileged students.

We have investigated persistence using the Likert scale, which has nine items in two blocs. The first bloc summarizes commitment to graduate, conviction about the benefits of studies, determination to achieve the best possible results, and the strength of intent to participate in academic activities. The second bloc comprises self-confidence to take on and complete different forms of academic activities, and confidence about time management, and the ability to concentrate on one task. The scale of persistence has a high reliability measure (Cronbach's $\alpha=.921$ ). We have conducted principal component analysis of the nine variables, which has yielded an explained variance of $61.4 \%$.

In this analysis, we have divided social networks into four segments, and have compared the strength of relationships within and outside the institution (intraorganizational and extraorganizational) as well as of intergenerational and intragenerational ties. The reliability measure of the scale of intraorganizational and intergenerational relationships is high (Cronbach's $\alpha=.835)$. Principal component analysis of the eight variables has resulted in an explained variance of $68.7 \%$. When principal component analysis has been conducted on a bloc of 11 variables with high Cronbach's $\alpha$ (.847), about $59.8 \%$ of the variance has been explained, 
which is an acceptable value. The questions about extraorganizational and intragenerational relationships have a Cronbach's $\alpha$ of .888. Principal component analysis on the 12 variables has shown that $58.7 \%$ of the variance can be explained. The strength of extraorganizational and intergenerational ties, that is, the content and strength of contact with parents have been measured on a 12-item ordinal scale. The items refer to various forms of contact: doing chores together, parents' interest in their child's studies, motivating to study, contact with the students' partners at the institution, donations, activities together, and finally, students' conversations with their parents about general topics, culture, politics, public affairs, books, films, career choices, and leisure activities. The scale that describes the strength of parent-student relationships has a high reliability measure (Cronbach's $\alpha=.886$ ). We have conducted principal component analysis of the 12 variables, which has yielded an explained variance of $58.9 \%$. All variables have been standardized, and have been used both as continuous and binary variables (under or above the mean). It has been revealed that strong, intraorganizational, and intragenerational relationships are the most frequent, whereas intraorganizational and intergenerational ties are rare. To examine the connections between basic demographic and social status indicators on the institutional and individual level, we have first employed binary analyses (contingency analysis and comparing means), and then multistep logistic regression analysis.

\section{Facts about attrition and student persistence}

We have compared actual data of discontinued studies at faculties of an Eastern Hungarian university with the scale we have created to predict attrition risk. The Higher Education Information System (FIR) contains data for 2010 and 2014 on the institutional level, which we have used to examine the ratios of graduations and discontinued studies. This has allowed us to create a ranking based on attrition risk. We have compared the ranking with higher education persistence indicators from our 2015 survey study. Data from FIR suggest that few faculties exhibit a non-completion rate below $25 \%$ steadily over time. The same faculties are the ones in the 2015 survey data with $80 \%$ or more students who are convinced about the usefulness of their studies in their careers, are determined to graduate, wish to achieve the best possible results and to take a great number of courses, claim that they are able to meet deadlines and to postpone leisure activities to concentrate on studying and lectures. Based on the survey, faculties with high attrition rates tend to have fewer persistent students.

According to the 2015 survey data, about one eighth of respondents $(13 \%)$ have discontinued their degree program before. Three quarters of them are first-year or second-year students, that is, they are at the beginning of a new program. Of the $13 \%$, three quarters have departed from their bachelor's studies, with two thirds studying in another bachelor's program. At certain faculties and in some regions, it is often students whose parents have a high level of education who discontinue their studies, suggesting that the parents' high level of education does not imply low attrition rates automatically. It is important to note that having graduated once does not necessarily indicate persistence, although those who have discontinued their studies are less persistent than average, which means that they have a significant chance of non-completion again. In their analysis of data over multiple decades, Wolter et al. (2014) have reached similar findings. Consequently, it is worthwhile to investigate the factors that support students to become persistent in their studies.

\section{Becoming persistent and background variables}

Among the variable groups that we examined, individuallevel student attributes do not seem to be connected to persistence to a large extent. Perseverance with academic goals does not correlate significantly with important efficiency determinants, such as parents' level of education, objective, relative, and subjective financial situation, vocational secondary school, or maintainer of secondary school. Institutional variables seem to exert a much more significant impact. It can be shown, however, that there are more types of institutional environments, which benefit persistence. Institutions with a higher student count and greater academic achievements, as well as church-run universities strengthen the determination to graduate. This suggests that widely popular faculties of great prestige and institutional environments built around culture have a higher proportion of persistent students. By contrast, strong selectivity does not seem to encourage students to become persistent.

Besides institutional characteristics, the ambiguity described above may also result indirectly from factors of student embeddedness in social networks. This presumption is reinforced by the fact that two individual factors, which influence persistence, namely place of residence in a large town and accommodation in a student dormitory, suggest proximity to the institutions in terms of location and social networks. Similarly to efficiency, female students' persistence seems to be stable (Table 1).

According to previous multivariate analyses, the mechanism through which institutions can exert an influence includes the quantity, quality, and value-transferring function of student connections within the institution, which has been shown in a comprehensive review of international literature findings (Pascarella \& Terenzini, 2005) and in a study based on Hungarian data, as well (Pusztai, 2015). Based on our previous work on student embeddedness and the most popular concept of higher education attrition, namely Tinto's student integration theory, we have investigated the effects of student embeddedness in social networks on persistence indicators, which are predictive of student attrition, along intergenerational or intragenerational and intraorganizational or extraorganizational axes.

\section{THE IMPACT OF INDIVIDUAL AND EMBEDDEDNESS FACTORS ON STUDENT PERSISTENCE}

In our analysis, we have attempted to show the impact of institutional, individual, and embeddedness indicators on student persistence. We have analyzed the chance of becoming persistent in models, which control for the simultaneous effect of different variables, and have calculated 
Table 1. The relationship between becoming an above average persistent student and basic variables

\begin{tabular}{lcc}
\hline & $\begin{array}{c}\text { Attribute that strengthens student } \\
\text { persistence the most }\end{array}$ & $\begin{array}{c}\text { Significance } \\
\chi^{2} / \text { ANOVA }\end{array}$ \\
\hline Institution attributes & Higher student count \\
Size & Church-run & 0.003 \\
Maintainer & - & 0.004 \\
Strong selectivity & Great academic achievements & NS \\
Excellence of lecturers & Majority institution & 0.000 \\
Minority/majority higher education & & 0.000 \\
Student attributes & Female & 0.000 \\
Gender & - & NS \\
Father's level of education & - & NS \\
Mother's level of education & - & NS \\
Financial situation (objective, relative, and subjective) & Large town \\
Place of residence & Student dormitory & 0.032 \\
Accommodation during the academic year & Not a member & 0.037 \\
Organization membership & - & 0.000 \\
Vocational secondary school & - & NS \\
Maintainer of secondary school & NS \\
\hline
\end{tabular}

Note. Source: IESA student survey performed in 2015. ANOVA: analysis of variance.

estimates. Variable groups have been included in our logistic regression models in four steps. In the first step, we have examined institutional characteristics, which all affect student persistence positively: students are more persistent if they attend institutions with a higher student count and great research achievements, and if they study at selective or church-run faculties. Including gender and socioeconomic status, indicators in the model has eliminated the significance of the maintainer, while the inclusion of residence and previous school experience has caused the previously significant effect of research achievements to disappear. On the contrary, the impact of size and selectivity has remained significant, with increasing coefficients in some cases. This suggests that it is students at remarkably selective institutions with high admission requirements who are most determined to graduate successfully. In all specifications, female students are significantly more persistent than their male peers. In this multivariate analysis, parents' level of education does not seem to influence student persistence, whereas a beneficial financial situation has a significant adverse effect on it. Perseverance with academic goals is not affected by dormitory accommodation during the academic year, place of residence, and previous education environment. With regard to institutional connections,

Table 2. The impact of institutional, individual, and embeddedness indicators on student persistence

\begin{tabular}{|c|c|c|c|c|}
\hline & 1 & 2 & 3 & 4 \\
\hline Size & $1.257^{* *}$ & $1.335 * * *$ & $1.217 * *$ & $1.220 * *$ \\
\hline Selectivity & $1.927 * *$ & $2.182 * *$ & $2.290 * *$ & $2.462 * *$ \\
\hline Maintainer & $2.263^{* *}$ & $1.913^{* *}$ & 1.570 & 1.431 \\
\hline Research achievements & $1.373 * *$ & 1.254 & 1.191 & 1.136 \\
\hline Gender & & $0.490 * * *$ & $0.487 * * *$ & $0.553 * * *$ \\
\hline Father's level of education & & 0.945 & 0.951 & 0.947 \\
\hline Mother's level of education & & 1.006 & 0.996 & 0.938 \\
\hline Financial situation tertiles & & $0.838^{* *}$ & $0.841 * *$ & $0.802 * *$ \\
\hline Place of residence & & & 1.089 & 1.127 \\
\hline Accommodation during the academic year & & & 1.208 & 1.183 \\
\hline Vocational secondary school & & & 1.064 & 1.074 \\
\hline Maintainer of secondary school & & & 0.989 & 1.010 \\
\hline Intraorganizational and volunteering & & & $0.754 * *$ & $0.731 * *$ \\
\hline Intraorganizational and intergenerational & & & & $1.577 * * *$ \\
\hline Intraorganizational and intragenerational & & & & 1.170 \\
\hline Extraorganizational and intragenerational & & & & 1.090 \\
\hline Extraorganizational and intergenerational & & & & $1.962 * * *$ \\
\hline Intercept & $0.629 * * *$ & 1.058 & 1.120 & 0.557 \\
\hline$-2 L L$ & 1.4 & 3.4 & 3.9 & 6.9 \\
\hline
\end{tabular}

Note. Source: IESA student survey performed in 2015 . The fit of models is indicated by the decrease of $-2 * \operatorname{loglikelihood}(2 \mathrm{LL})$ value in percentage terms.

$* * * p=.000 .{ }^{* *} p<.03 .{ }^{*} p<.05$. 
participation in intraorganizational volunteer groups decreases, whereas intergenerational ties increase the likelihood of becoming persistent among students. In our previous studies, we already established the positive effects of intergenerational social embeddedness, but now it has been shown for the first time that parents' involvement in various dimensions also has a significant impact (Table 2).

\section{CONCLUSIONS}

This study contributes to research on the complex phenomenon of student attrition. Our analysis has reassured that attrition and uncertain student persistence are a relevant focus for research. Our data show that those who have discontinued a degree program in the past are less persistent than the average, that is, they have a significant chance of non-completion again. To predict successful completion of higher education studies, we have been using our own questionnaire since 2012. We have measured student persistence on a 9-item Likert scale, with standardized and binary variables. We have shown that faculty-level ratios of discontinued studies negatively correlate with the persistence scale, which we have created to capture perseverance with higher education studies. We have also explored the reasons as to why a student becomes persistent. Our explanations have included bivariate analysis with institutional characteristics, individual-level demographic and social indicators, social network factors, as well as multivariate logistic regression models. Our findings have revealed that factors in connection with the institutions and social networks have a larger, more significant impact than individual indicators. Contrary to expectations, selective institutions have a higher proportion of students who are eager to complete their studies successfully, possibly motivated by the high prestige of their field and profession in the future. Female students are more committed to academic goals. This finding is not unprecedented in the Hungarian and international literature: some have even suggested that the entry of women into higher education in the 1970's caused the trend of falling attrition rates (Engler, 2013; Fényes, 2010; Wolter et al., 2014). The phenomenon is often attributed to social expectations toward women and family norms, but the explanation may also include females' more advanced ability to make contacts.

It is clear that student persistence is reinforced by strong, multiplex relationships with lecturers and professors. Even more pronounced is the effect of the relationship with parents. In accordance with recent international literature, we note that normative judgment in this matter should be avoided. With higher education becoming more impersonal, formal, and extensive, which leaves the need for stable social support unsatisfied, the importance of close and complex student-parent relationships is likely to be substantial.

It seems that students' favorable financial background hinders their persistence instead of enhancing it. Students who are better off than the average may not feel the need to use higher education as a path to achieve high status. Multivariate analyses have revealed that intraorganizational and extraorganizational volunteer work and group membership do not exert a significant effect. The impact of participating in intragenerational social networks on student persistence requires further analysis.

Our findings suggest that it might be worthwhile to consider adapting policies of higher education institutions to current circumstances. Besides ensuring multidimensional and varied support for students by lecturers and professors, establishing and maintaining a system of services for parents might also improve student persistence.

Funding sources: Project no. 123847 has been implemented with the support provided from the National Research, Development and Innovation Fund of Hungary, financed under the K_17 funding scheme.

Author's contribution: The author has full access to the references included in this analysis and takes responsibility for the integrity and accuracy of the study.

Conflict of interest: The author declares no conflict of interest.

\section{REFERENCES}

Altbach, P. G. (2009). Introduction. In R. B. Ludeman \& K. J. Osfield (Eds.), Student affairs and services in higher education: Global foundation issues and best practices. Paper presented by International Association of Student Affairs and Services (IASAS) XIII-XIV. Paris, France: United Nations Educational, Scientific and Cultural Organization.

Astin, A. W. (1993). What matters in college: Four critical years revisited. San Francisco, CA: Jossey-Bass. Retrieved from https://mountainscholar.org/bitstream/handle/10217/16692/ JOUF_JSA1994.pdf? sequence $=1 \#$ page $=79$

Barefoot, B. O. (2004). Higher education's revolving door: Confronting the problem of student dropout in US colleges and universities. Open Learning, 19(1), 9-18. doi:10.1080/ 0268051042000177818

Braxton, J. (Ed.). (2000). Reworking the student departure puzzle (pp. 127-156). Nashville, TN: Vanderbilt University Press.

Ceglédi, T., Tóbi, I., \& Harsányi, Sz. (2016). Reziliens hallgatók és szakkollégiumi felvételi szelekció [Resilient students and college selection]. Educatio, 25(3), 359-371. Retrieved from http://epa.oszk.hu/01500/01551/00097/pdf/EPA01551_ educatio_2016_3_359-371.pdf

Derényi, A. (2015). Bizonyítékokra alapozott kormányzás és a kommunikáció képzés [An evidence based traning on communication]. Jelkép. Advance online publication. 1-21. doi:10. 20520/Jel-Kep.2015.1.KLSZ.21

Engler, A. (2013). Students with small children in higher education. Journal of Social Research and Policy, 4(1), 109-120. Retrieved from http://real.mtak.hu/15157/1/Engler\%20Student \%20with\%20\%20JSRP.pdf

Fényes, H. (2010). School efficiency of boys and girls in a borderland region of Hungary. Review of Sociology of the Hungarian Sociological Association, 6(1), 51-77.

Fenyves, V., Bácsné, B. É., Szabóné, Sz. R., Kocsis, I., Juhász, Cs., Máté, E., \& Pusztai, G. (2017). Kísérlet a lemorzsolódás mértékének és okainak megragadására a Debreceni Egyetem 
Gazdaságtudományi Kar példáján [An attemption to capture the degree and causes of drop-out at the University of Debrecen Faculty of Economics]. Neveléstudomány: Oktatás, kutatás, innováció, 7(3), 5-14. doi:10.21549/NTNY.19.2017.3.1

French, B. F., Immekus, J. C., \& Oakes, W. C. (2005). An examination of indicators of engineering students' success and persistence. Journal of Engineering Education, 94(4), 419-425. doi:10.1002/j.2168-9830.2005.tb00869.x

Hatos, A., \& Pop, A. (2013). Commitment to the goal of completing studies in higher education. Dropout risk of the students from social science specialisation from the three Romanian public universities that participate in Project Practipass. Annals of University of Oradea, Fascicle Sociology-Philosophy \& Social Work, 12, 5-16. Retrieved from http://socioumane.ro/ blog/analesocioumane/files/2013/11/Commitments-to-the-goalof-completing-studies-in-higher-education.pdf

Heublein, U. (2014). Student drop-out from German higher education institutions. European Journal of Education, 49(4), 497-513. doi:10.1111/ejed.12097

Huber, L. (1991). Sozialisation in der Hochschule. In K. Hurrelmann \& D. Ulich (Eds.), Neues Handbuch der Sozialisationsforschung [Socialization in higher education] (pp. 417-441). Weinheim, Germany/Basel, Switzerland: Beltz Verlag S. Retrieved from https://pub.uni-bielefeld.de/ download/1781658/2313402

Kehm, B. (2014). Editorial. European Journal of Education, 49(4), 453-456. doi:10.1111/ejed.12092

Kim, D. H., \& Schneider, B. (2005). Social capital in action: Alignment of parental support in adolescents' transition to postsecondary education. Social Forces, 84(2), 1181-1206. doi:10.1353/sof.2006.0012

Mortenson, T. G. (2012). Measurements of persistence. In A. Seidman (Ed.), College student retention: Formula for student success (pp. 35-59). Lanham, MD: Rowman \& Littlefield.

Nakajima, M. A., Dembo, M. H., \& Mossler, R. (2012). Student persistence in community colleges. Community College Journal of Research and Practice, 36(8), 591-613. doi:10.1080/ 10668920903054931

Pascarella, E. T., \& Terenzini, P. T. (1980). Predicting freshman persistence and voluntary dropout decisions from a theoretical model. Journal of Higher Education, 51(1), 60-75. doi:10.2307/ 1981125

Pascarella, E. T., \& Terenzini, P. T. (2005). How college affects students. A third decade of research. San Francisco, CA: JosseyBass. Retrieved from https://edocs.uis.edu/Departments/LIS/ Course_Pages/LIS301/papers/How_college_effects_students_ 534-545.pdf

Perna, L. W., \& Titus, M. A. (2005). The relationship between parental involvement as social capital and college enrollment: An examination of racial/ethnic group differences. The Journal of Higher Education, 76(5), 485-518. doi:10.1353/ jhe. 2005.0036

Pusztai, G. (2009). Mentor vagy idol?: A doktorandusz-témavezető kapcsolat formái a tudományos utánpótlásképzésben [Mentor or idol: The forms of supervisor and PhD student]. In G. Pusztai \& M. Rébay (Eds.), Kié az oktatáskutatás? [Who is involved in education research?] (pp. 337-353). Debrecen, Hungary:
Csokonai Kiadó. Retrieved from http://cherd.unideb.hu/iesa/ dok/Pusztai_G-Mentor_vagy_idol.pdf

Pusztai, G. (2015). Pathways to success in higher education. Frankfurt am Main, Germany: Peter Lang Verlag.

Pusztai, G. (2017). A felsőoktatás értéke az audit-társadalomban [Higher education in audit society]. Magyar Tudomány, 178(11), 1399-1412. doi:10.1556/2065.178.2017.11.7

Pusztai, G., Bocsi, V., \& Ceglédi, T. (Eds.). (2016). A felsőoktatás (hozzáadott) értéke [Value added in higher education]. Oradea, Budapest: Partium. Retrieved from mek.oszk.hu/16000/16053/ 16053.pdf

Pusztai, G., \& Szabó, P. C. (2008). The Bologna process as a Trojan Horse. European Education, 40(2), 85-103. doi:10. 2753/EUE1056-4934400205

Reay, D., Crozier, G., \& Clayton, J. (2009). Strangers in Paradise? Working-class students in Elite Universities. Sociology, 43(6), 1103-1121. doi: $10.1177 / 0038038509345700$

Sciarra, D. T., Seirup, H. J., \& Sposato, E. (2016). High school predictors of college persistence: The significance of engagement and teacher interaction. The Professional Counselor, 6(2), 189-202. doi:10.15241/ds.6.2.189

Somlai, P. (1997). Szocializáció. A kulturális átörökítés és a társadalmi beilleszkedés folyamata [Socialization: The process of cultural transmission and social integration]. Budapest, Hungary: Corvina.

Szczepanski, J. (1969). A felsőoktatás szociológiája [Sociology of higher education]. Budapest, Hungary: Felsőoktatási Pedagógiai Kutatóközpont.

Tierney, W. G. (2000). Power, identity and dilemma of college student departure. In J. M. Braxton (Ed.), Reworking the student departure puzzle (pp. 213-235). Nashville, TN: Vanderbilt University Press.

Tinto, V. (1975). Dropout from higher education: A theoretical synthesis of recent research. Review of Educational Research, 45(1), 89-125. doi:10.3102/00346543045001089

Tinto, V. (1993). Leaving college: Rethinking the causes and cures of student attrition. Chicago, IL: University of Chicago Press. Retrieved from https://eric.ed.gov/?id=ED283416

Ulriksen, L., Madsen, M. L., \& Holmegaard, T. H. (2017). The first-year experience of non-traditional students in Danish science and engineering university programmes. European Educational Research Journal, 16(1), 45-61. doi:10.1177/ 1474904116678628

Wartman, K. L., \& Savage, M. (2015). Parent and family engagement in higher education. ASHE, 41(6), 1-94. doi:10.1002/ aehe. 20024

Weidman, J. C., \& Stein, E. L. (2003). Socialization of graduate students to academic norm. Research in Higher Education, 44(6), 641-656. doi:10.1023/A:1026123508335

Wolf, D. S., Sax, L., \& Harper, E. C. (2009). Parental engagement and contact in the academic lives of college students. Journal of Student Affairs Research and Practice, 46(2), 325-358. doi:10.2202/1949-6605.6044

Wolter, S. C., Diem, A., \& Messer, D. (2014). Drop-outs from Swiss Universities: An empirical analysis of data on all students between 1975 and 2008. European Journal of Education, 49(4), 471-483. doi:10.1111/ejed.12096 